\title{
1 A mixed Ediacaran-metazoan assemblage from the Zaris Sub-basin, Namibia
}

3 Simon A.F. Darroch* ${ }^{1,2}$, Thomas H. Boag ${ }^{3}$, Rachel A. Racicot ${ }^{2,4}$, Sarah Tweedt ${ }^{2}$, Sara J.

4 Mason $^{5}$, Douglas H. Erwin ${ }^{2}$, and Marc Laflamme

$6{ }^{1}$ Department of Earth and Environmental Sciences, Vanderbilt University, 2301

7 Vanderbilt Place, Nashville, TN. 37235-1805 USA

$8{ }^{2}$ Smithsonian Institution, PO Box 37012, MRC 121, Washington, DC. 20013-7012 USA

$9{ }^{3}$ Department of Geological Sciences, Stanford University, 450 Serra Mall, Building 320,

10 Room 118, Stanford, CA, 94305-2115

$11{ }^{4}$ The Dinosaur Institute, Natural History Museum of Los Angeles County, 900 Exposition

12 Blv., Los Angeles, CA. 90007 USA

$13{ }^{5}$ Department of Chemical and Physical Sciences, University of Toronto Mississauga,

143356 Mississauga Road North, Ontario. L5L 1 C6 Canada

$15 *$ Corresponding author

17 Email addresses: $\underline{\text { simon.a.darroch@vanderbilt.edu, tomboag@ stanford.edu, }}$

18 rracicot@nhm.org, tweedts@si.edu, s.mason@mail.utoronto.ca, Erwind@ si.edu,

19 marc.laflamme@utoronto.ca

(C) 2016. This manuscript version is made available under the Elsevier user license http://www.elsevier.com/open-access/userlicense/1.0/ 


\section{ABSTRACT}

26 It has been proposed that the terminal Neoproterozoic Ediacara biota were driven to

27 extinction by the evolution of metazoan groups capable of engineering their

28 environments (the 'biotic replacement' model). However, evidence for an overlapping

29 ecological association between metazoans and soft-bodied Ediacaran organisms is

30 limited. Here, we describe new fossil localities from southern Namibia that preserve soft-

31 bodied Ediacara biota, enigmatic tubular organisms thought to represent metazoans, and

32 vertically-oriented metazoan trace fossils. Although the precise identity of the

33 tracemakers remains elusive, the structures bear several striking similarities with the

34 Cambrian-Recent ichnogenus Conichnus. These new data support inference of

35 stratigraphic and ecological overlap between two very different eukaryotic clades, and

36 indicate the existence of unusual ecosystems comprising both Ediacara biota and

37 metazoans immediately prior to the Cambrian explosion.

39 Keywords: Ediacaran; Cambrian; metazoans; trace fossil; ecosystem engineering;

40 Conichnus, Shaanxilithes, Aspidella 


\section{Introduction}

The terminal Neoproterozoic (Ediacaran; 635 - $541 \mathrm{Ma}$ ) Ediacara biota is an

50 enigmatic assemblage of large, morphologically complex eukaryotes. The biological

51 affinities of the Ediacara biota are controversial (Xiao and Laflamme, 2009; Laflamme et

52 al., 2013), however it is likely that most groups represent multicellular eukaryotes that

53 went extinct prior to the Cambrian radiation of bilaterian metazoans. With the exception

54 of a few isolated occurrences (Jensen et al., 1998; Hagadorn and Waggoner, 2000),

55 Ediacara-type fossils are largely absent from Cambrian and younger strata despite

56 favorable preservational settings (Buatois et al., 2014). To account for this extinction

57 event at the end of the Ediacaran, Laflamme et al. (2013) proposed a 'biotic replacement

58 model' whereby early members (or precursors) of the Cambrian evolutionary fauna

59 gradually displaced Ediacaran biotas through a combination of predatory displacement

60 (see also Seilacher, 1992; Bengston and Yue, 1992; Hua et al., 2003) and ecological

61 engineering of Ediacaran-type ecosystems. The 'biotic replacement' model for the end of

62 the Ediacara biota therefore predicts a protracted Ediacaran turnover involving significant

63 stratigraphic overlap between soft-bodied Ediacara biota, and organisms more typical of

64 the Cambrian evolutionary fauna (Seilacher, 1992; Laflamme et al., 2013; Schiffbauer et

65 al., in press).

66 Despite this hypothesized lengthy overlap of Ediacaran macrobiota and metazoan

67 ecosystem engineers, few sites preserve fossil evidence for co-occurrence of these

68 groups. Instead, review of older (i.e., 'White Sea' assemblage) Ediacaran sections

69 suggests a different scenario, in that direct (i.e., same bed or same slab) associations 
70 between Ediacara biota and metazoans are almost universally rare (see Chen et al., 2014

71 for a possible exception). This is in part due to careful specimen-based work that has led

72 to re-descriptions of many Ediacaran 'trace-fossils' in pre-Nama assemblages as body

73 fossils (see Jenson et al., 2005; 2006; Sappenfield et al., 2011), such that

74 Helminthoidichnites is the only trace fossil from this interval still universally viewed as

75 representing a metazoan (and specifically bilaterian) tracemaker. Here, we describe new

76 fossil localities from the youngest Ediacaran strata in southern Namibia that preserve

77 Ediacara biota, enigmatic tubular organisms thought to represent metazoans, and

78 vertically oriented trace fossils characteristic of Cambrian-type metazoan activity.

80 2. Geological Setting

The Nama Group in southern Namibia is divided into two sub-basins separated by

83 a paleo-topographic high. The Proterozoic to Cambrian-aged Nama Group (Schwarzrand

84 Subgroup) forms a mixed siliciclastic-carbonate succession deposited in a foreland basin

85 on the western and northern margins of the Kalahari craton (Germs, 1983; Grotzinger et

86 al., 1995; Saylor et al., 1998; Vickers-Rich et al., 2013). Regionally, the Schwarzrand

87 Subgroup is underlain by mixed carbonate and clastic sediments of the Kuibis subgroup,

88 which includes microbial-metazoan reef complexes (Grotzinger et al., 2000; Penny et al.,

89 2014). Overlying Schwarzrand strata record subsequent regional shallowing, and are

90 composed of shales, siltstones, and sandstones representing deposition in a range of tide-

91 and delta-influenced shoreface environments (Germs, 1983; Grotzinger et al., 1995;

92 Saylor et al., 1998). 
There are few geochronological constraints for the Schwarzrand Subgroup in the

94 Zaris sub-basin, although coeval sections from the Spitzkopf Formation are dated as

95 Ediacaran in the southern Witputs sub-basin (545 $\pm 1 \mathrm{Ma}-$ Grotzinger et al., 1995). An

96 ash bed from the underlying Kuibis Subgroup (Hoogland Member) in the vicinity of our

97 sites yields a U-Pb zircon age of $548.8 \pm 1 \mathrm{Ma}$ (Grotzinger et al., 1995) and so gives a

98 maximum age for the Schwarzrand (Figure 1). The overlying Fish River Subgroup

99 contains abundant trace fossils (Geyer, 2005), including Treptichnus pedum, which marks

100 the base of the type section of the Fortunian (lowermost Cambrian) at the Global

101 Stratotype (GSSP) for the Cambrian System at Fortune Head, Canada (Narbonne et al.,

102 1987; Brasier et al., 1994). Work by Geyer (2005) suggests that the Proterozoic-

103 Cambrian transition in the Zaris may be located as low as the middle Schwarzrand

104 Subgroup, however, given the absence of Treptichnus pedum in Schwarzrand sections

105 within the Zaris sub-basin, we follow Grotzinger et al. (1995) in considering these

106 sections latest Ediacaran.

107

108 3. Body fossils

109

110 This is the first report of soft-bodied Ediacaran macrobiota from the Zaris sub-

111 basin, and expands the known geographic range of Ediacaran-type macrofossils in

112 Namibia (see Boag et al., 2016). We recovered numerous Aspidella-type Billings, 1872

113 discoidal Ediacaran fossils both in-situ and from float material (Table 1; Figure 2). All

114 localities preserve abundant and well-developed microbially induced sedimentary

115 structures ('MISS'), indicating colonization of the substrate by seafloor microbial mats. 
116 In localities S.04, S.011, and S.014, Aspidella were discovered preserved in finer-grained

117 siltstones and shales (Table 1), at times preserving both part-and-counterpart impressions

118 (Figure 3). In localities S.015 and S.019, large Aspidella were found preserved in

119 negative epirelief on the top surfaces of fine-grained sandstone beds, with symmetric

120 ripples indicating influence by waves and/or bidirectional currents in relatively shallow-

121 water paleoenvironments above wave-base.

122 The affinities of Aspidella are controversial, however, given the consistent

123 morphological architecture and the rigid outer boundary of these forms, our reported

124 Aspidella fossils likely represent the rooting holdfast of frondose taxa whose affinities

125 are, at present, impossible to discern without an accompanying frond (Laflamme and

126 Narbonne, 2008). At sites S.015 and S.019, these holdfast structures are particularly

127 abundant ( $\mathrm{n}=>15$ ), large (up to $8 \mathrm{~cm}$ in diameter), and exhibit a broad size-frequency

128 distribution suggesting a well-established and tiered community at a late stage of

129 ecological succession (Figure 4). Given the robust positive relationship between

130 Ediacaran holdfast diameters and accompanying frond size (Burzynski and Narbonne,

131 2015), these Aspidella fossils lend themselves to analysis of population structure; we

132 therefore used Bayesian Information Criterion ('BIC'; a model-based clustering method)

133 using the package Mclust (Fraley and Raftery, 1999) in R to establish the most likely

134 number of cohorts represented in the preserved community (Darroch et al., 2013; Zamora

135 et al., 2013; Zakrevskaya, 2014; Hall et al., 2015). The results indicate virtually identical

136 BIC values for 1- and 2-group solutions when variances in groups are allowed to be

137 flexible (which is more biologically realistic than when variances are assumed equal,

138 Darroch et al., 2013). This particular assemblage may reflect a community constructed 
139 through multiple recruitment events and thus composed of multiple generations. This

140 result would run counter to those from deep-water settings, but is similar to those

141 obtained from shallow-water settings where seasonal changes in temperature might be

142 expected to trigger synchronous gamete production and release (Darroch et al., 2013;

143 Zakrevskaya et al., 2014). However, since the sample size for this analysis $(n=15)$ is

144 relatively low and we assume that these holdfasts all represent a single species, this result

145 should be considered preliminary until accompanying fronds are discovered.

146 In addition to Aspidella, at locality S.015 we recovered dense accumulations of

147 elongate and annulated fossils similar to those reported from the Ediacaran of China

148 preserved as positive structures on the top surfaces of beds (i.e. positive epirelief; Figure

149 2; also see Cai and Hua, 2011). These organisms are typically tube- or ribbon shaped,

150 have consistent width (1-6 mm; Figure 6), and possess closely spaced transverse

151 annulations. The tubes maintain consistent width throughout their length without conical

152 apices or evidence for flared apertures, and so are easily distinguished from other

153 precambrian tube-like organisms, such as either Cloudina Pflug, 1972 (which is abundant

154 throughout the Nama Group, see Grotzinger et al., 1995; Wood and Curtis, 2014), or the

155 Cloudina-like organism Conotubus (Cai et al., 2011). Even though skeletonized tubes

156 preserved in siliclastics may look similar to other soft-bodied tubes, the length of the

157 organisms described here, and presence of linked annulations (rather than cone-in-cone

158 morphology - see Hua et al., 2005) comprise strong evidence that they do not represent

159 Cloudina. Cohen et al. (2009) described a variety of tube-like fossils from the Nama

160 Group, including the ribbon-like taxon Vendotaenia, however, these are preserved

161 differently (as organic compressions), and lack the prominent annuli visible in our fossils. 
162 The range of tube diameters fall for our organisms firmly inside the distributions

163 recorded by Cai and Hua (2011) and Tarhan et al. (2014) for Shaanxilithes Xing et al.,

164 1984, and outside those recorded for the morphologically similar (but larger)

165 Gaojiashania Lin et al., 1986, allowing tentative identification as Shaanxilithes

166 ningqiangensis (Figure 6e). This taxon is reported from China (Cai et al., 2012), Siberia

167 (Zhuravlev et al., 2009), and India (Tarhan et al., 2014) where it is restricted to upper

168 Ediacaran rocks, and has been suggested as a candidate index fossil for the latest

169 Ediacaran (Meyer et al., 2012). In China, Shaanxilithes is typically preserved as two-

170 dimensional clay molds (Meyer et al., 2012; Tarhan et al., 2014), however, the specimens

171 reported here are instead preserved as casts and molds typical of soft-bodied Ediacaran

172 macrofossils, in both positive and negative relief on the weathered tops and undersurfaces

173 of fossil slabs (i.e. both positive epirelief and negative hyporelief). Individual organisms

174 exhibit overlapping, but not crosscutting relationships, reinforcing interpretations by

175 previous authors (Cai et al., 2011; Meyer et al., 2012) that these structures represent body

176 fossils rather than trace fossils. Although some surface textures in association with

177 Shaanxilithes could represent disarticulated individual annuli (Figure 2d), the majority

178 are fully articulated, suggesting that the specimens were rapidly buried, or instead may

179 have maintained a shallow infaunal (or under-mat) habit during life, and were preserved

180 in life-position.

181 In addition, fossil slabs bearing dense accumulations of Shaanxilithes also

182 preserve numerous Aspidella holdfast structures (see Laflamme et al., 2004) preserved in

183 negative epirelief (Figure 6). Given that there is little evidence for post-mortem transport

184 in the Shaaxilithes specimens (given by the low frequencies of disarticulation - see 
185 Meyer et al., 2012), this observation would indicate that Shaanxilithes were likely living

186 in extremely close association with Ediacaran frondose organisms.

\section{4. Trace fossils}

At localities S.015 and S.019, vertically oriented trace fossils (Figures 2,5) are

191 preserved in a variety of lithologies (see Table 1) but most commonly in fine-grained and

192 rippled sandstones indicative of shallow water, subtidal paleoenvironments. Burrows

193 occur in the same outcrops as Ediacaran body fossils, separated by as little as $\sim 10 \mathrm{~cm}$ of

194 stratigraphy (Figure 1). In gross morphology, trace fossils are preserved as positive relief

195 mounds on bed top surfaces (i.e. positive epirelief - Figure 2e,f,h) and as conical

196 'dimples' surrounded by concentric pits on bed bottom surfaces (i.e. negative hyporelief

197 with positive central boss - Figure 2g). Although trace fossils often appear paired in

198 samples (Figure 2e-h), cross-sectional views illustrate that they do not join in the

199 subsurface as ' $\mathrm{u}$ '-bends, and instead appear vertical, sometimes $>5 \mathrm{~mm}$ in depth and

200 typically 3-5 $\mathrm{mm}$ in diameter. Trace fossils truncate sedimentary laminae, which bend

201 upwards into the burrow suggesting progressive upwards-movement of the organism in

202 life (Figure 5b,d; Abad et al., 2006). These are best seen in thin mud drapes separating

203 sedimentary laminae. Further evidence of upward movement of the organism during life

204 is shown in some specimens by the preservation of stacked conical (chevron) burrow

205 infill ('equilibrichnion'), which represents adjustment to sediment accumulation (Desai

206 and Saklani, 2015). The boundaries between matrix and burrow infill can be either sharp 
207 or diffuse, suggesting either that mucus linings were not originally present, or that they

208 decayed before preservation in some areas.

209 The structures exhibit several features that negate an abiotic origin or

210 interpretation as water- or gas-escape structures (see e.g., Menon et al., 2016). First, the

211 conical/chevron infill visible in some examples is oriented concave-upwards, which is

212 inconsistent with gas escape (Frey et al., 2008). Moreover, no convolute bedding (which

213 is a common product of gas escape via aggregative fluidization - see Frey et al., 2008)

214 was seen in any polished sections. Although water-escape structures can sometimes result

215 in downwards-collapse of sediment (see Nichols et al., 1994; Frey et al., 2008) this

216 typically destroys structure within the column. In the structures described here, laminae

217 are more commonly seen deflected upwards into the edges of the column and preserve

218 fine-grained chevron infill (Figure 5), and are thus more consistent with the upward

219 movement of an organism. This upwards deflection of laminae into the core of the

220 burrow is particularly characteristic of some common Phanerozoic trace fossils (see e.g.,

221 Figure 5 in Abad et al., 2006), rather than gas or fluid escape. Second, in some examples

222 thin mud drapes can be seen extending laterally from the matrix down into the base of

223 infill chevrons; this illustrates that laminae are not always cross-cut (as is typical for both

224 gas- and water-escape structures), but instead sediment was able to accumulate alongside

225 the organism, and settled into the core of the burrow as the organism adjusted its position

226 upwards. Almost all of these features are at odds with the Medusinites and

227 Beltanelliformis fossils reinterpreted by Menon et al. (2016) as fluid escape structures,

228 which typically do not extend deeper than $1 \mathrm{~mm}$ (the examples described here penetrate

$229>5 \mathrm{~mm}$ ), apparently rely on the presence of microbial mats for formation (which are not 
230 evident in our examples), and do not exhibit the combination of upwards-deflected

231 laminae and chevron cone-in-cone infill that is characteristic of biological behavior

232 (Abad et al., 2006). Moreover, we do not see any horizontal sill-like 'injections' of

233 sediment, which would suggest an abiotic origin as a sand volcano (Menon et al., 2016).

234 An alternative possibility is that these structures represent body fossils. A variety

235 of putative Ediacaran trace fossils have recently been re-interpreted as body fossils

236 belonging to elongate or tube-like epibenthic organisms (Droser et al., 2006; Droser and

237 Gehling, 2008; Sappenfield et al., 2011), and as a result, it is possible that the structures

238 described here represent the remains of Ediacaran soft-bodied organisms that lived

239 anchored (or entirely) upright in the sediment. However, taphonomic experiments

240 conducted by Menon et al. (2013) suggest that processes of gravitational sediment

241 collapse into voids left by the decayed Ediacaran organisms do not typically produce the

242 characteristic meniscate and 'cone-in-cone' infill profile seen here. Moreover, this decay-

243 based model would also predict surface expression of collapse structures as a series of

244 negative-relief pits (i.e. negative epirelief - Narbonne, 2005; Gehling and Narbonne,

245 2007); instead, our trace fossils are preserved in positive epirelief on the top-surfaces of 246 beds.

248 5. Discussion

250 5.1 Trace fossils - The vertical trace fossils described here are best interpreted as small

251 Conichnus isp. Mayannil, 1966, which belong to the family of 'plug' shaped burrows

252 (Jensen and Runnegar, 2005; Buatois and Mangano, 2011). The chevron 'cone-in-cone' 
253 burrow infill most likely represents the activity of metazoan-grade organisms possessing

254 radial musculature, capable of adjusting their position relative to the sediment-water

255 interface. These burrows do bear some superficial resemblances to structures described

256 from Ediacaran-aged sediments from the Longmynd, UK (see Mcllroy et al., 2005),

257 however, they differ from these in a number of important aspects. Although the presence

258 of a circular depression with central mound is reminiscent of Intrites punctatus Fedonkin

2591980 (interpreted by McIlroy, 2005 as representing lower surface of an organism that was

260 largely sessile, but which had some propensity for movement), in cross section these

261 structures were characterized by parallel infill penetrated less than $1 \mathrm{~mm}$ into the

262 sediment; the examples described here possess unambiguous 'cone-in-cone' infill, and

263 sometimes penetrate $>5 \mathrm{~mm}$ into the sediment (indicating a much greater propensity for

264 upwards movement, presumably in order to keep pace with sedimentation). It seems

265 possible, however, that the Conichnus trace fossils reported here are part of a spectrum of

266 movement traces (including Intrites) belonging to sessile, soft-bodied and gregarious

267 metazoans that may have been relatively common in shallow marine settings in the

268 Ediacaran.

269 The Conichnus burrows described here are relatively small compared to

270 Phanerozoic examples; this observation matches those made by Crimes and Germs

271 (1983), who noted unusually small sizes among a variety of Ediacaran trace fossils in

272 Namibia (including Bergaueria Prantl, 1946, Diplocraterion Torell, 1870, and Nereites

273 MacLeay in Murchison, 1839) when compared to their Paleozoic counterparts. In

274 addition, similar burrows assigned to Conichnus were described by Jensen and Runnegar

275 (2005) from the southern Witputs sub-basin known to be latest Ediacaran, 
276 stratigraphically below sediments preserving Pteridinium Gürich, 1930 and the frondose

277 taxon Swartpuntia Narbonne et al., 1997 (Darroch et al., 2015), confirming stratigraphic

278 overlap between these trace fossil structures and soft-bodied Ediacara biota in southern

279 Namibia as well. Burrows with similar morphology (albeit larger) are known from

280 lowermost Cambrian rocks in Death Valley (Mata et al., 2012), and have a fossil record

281 that extends throughout much of the Phanerozoic (Abad et al., 2006; Curran, 2007).

282 Menon et al. (2013) described similar structures showing upward movement in much

283 older Ediacaran sections from Newfoundland; however, those structures are much larger

284 than the burrows described here, and apparently terminate in Aspidella holdfast-type

285 structures usually interpreted as belonging to frondose Ediacaran organisms. We observe

286 no direct association between Conichnus trace fossils and co-occurring Aspidella, and as

287 such the two structures cannot be interpreted as linked.

288 Although it is notoriously hard to reliably match trace fossils with specific

289 tracemakers, Conichnus-type burrows are almost universally attributed to anthozoan

290 cnidarians, including sea anemones (Actinaria) and tube anemones (Ceriantharia)

291 (Bromley, 1996; Abad et al., 2006; Buatois and Mangano, 2011; Mata et al., 2012;

292 Menon et al., 2013; Desai and Saklani, 2015), in part through observation of living

293 individuals in box cores (Gingras et al., 2008). Further support for inferring the existence

294 of anthozoan cnidarians in Ediacaran ecosystems comes from divergence time estimates

295 from molecular data, which suggest a split between Cnidaria and Bilateria in the

296 Cryogenian, and the divergence of Medusozoa from (ancestral) anthozoans sometime in

297 the Ediacaran (Erwin et al., 2011; Park et al., 2012). Moreover, molecular clock estimates

298 place the origin of the Hexacorallia in the lower Cambrian, a date consistent with the 
299 earliest known anemone body fossils (Hou et al., 2005; Rodgers, 2009). Under these

300 circumstances it is at least plausible that anthozoans were present alongside soft-bodied

301 Ediacara biota in the latest Ediacaran, however, in the absence of preserved body fossils

302 to corroborate this link, this assignment must remain speculative.

303

3045.2 The taxonomic affinity of Shaanxilithes - Despite its wide paleogeographic

305 distribution and the abundance of material, Shaanxilithes ningqiangensis has been the

306 subject of considerable taxonomic debate. More recent studies (Meyer et al., 2012;

307 Tarhan et al., 2014) have focused on the taphonomic characteristics of this taxon, making

308 a strong case for a body fossil, rather than trace fossil interpretation for these structures

309 (in particular the tendency for individuals to disarticulate, producing accumulations of

310 isolated annuli - see Meyer et al., 2012; see also Fig. 2d). Specific suggestions in terms

311 of biological affinity have included worms, algal debris, colonial bacteria, and

312 pognophoran tubes (summarized in Tarhan et al., 2014). However, detailed geochemical

313 investigation of Indian Shaanxilithes by Tarhan et al. (2014) using Laser-Raman

314 spectroscopic analysis indicated that fossils were preserved as organic kerogenous

315 compressions, comprising support for interpretation of Shaanxilithes as a multicellular

316 eukaryote, and (when morphological characteristics are taken into account) a likely

317 metazoan. Similarly, Cai et al. (2013) interpret the morphologically similar (and likely

318 phylogenetically related) taxon Gaojiashania as a tube-dwelling metazoan, following

319 detailed descriptions of complex, rigid ring-flexible bucket tube construction capable of

320 curving, extension, and constriction. 
3225.3 Mixed Ediacaran-metazoan communities - These new fossil localities preserve

323 Ediacaran Aspidella, body fossils of (probable) metazoan Shaanxilithes, and Conichnus

324 trace fossils within $20 \mathrm{~cm}$ of stratigraphy. These data indicate the coexistence of two very

325 different (and potentially of only distant phylogenetic relationship - see Xiao and

326 Laflamme, 2009) multicellular clades, soft-bodied Ediacarans and metazoans, within

327 latest Ediacaran ecosystems in Namibia. Although these organisms undoubtedly shared

328 an ecosystem, the question as to whether they formed close ecological associations is

329 more complicated and harder to test. Fossil slabs preserving dense accumulations of

330 Shaanxilithes along with numerous Aspidella holdfasts (Figure 6) indicate that these two

331 organisms were able to live in extremely close association, and may have exhibited more

332 complex biotic interactions. In contrast, Conichnus-type burrows are not found on slabs

333 with any evidence for any other organisms. More generally, Conichnus are locally

334 abundant where they occur in sediment with ripple cross-lamination showing little

335 evidence of colonization by microbial mats, whereas Ediacaran soft-body fossils occur in

336 close association with MISS, but are never found on the same surfaces as Conichnus

337 trace fossils. These observations are currently limited, but do suggest a preliminary model

338 of spatial and environmental niche partitioning between Ediacaran frondose organisms

339 and metazoan tracemakers in latest Ediacaran subtidal settings.

340 In a spatially heterogeneous tide- and delta-influenced shoreface environment,

341 Ediacaran fronds and infaunal (or epibenthic) Shaanxilithes would have colonized mat

342 stabilized substrates (perhaps in deeper water), with Conichnus trace-makers populating

343 higher-energy and shallower sub-environments. With Ediacaran frondose organisms

344 dependent on microbial mats for anchoring (Laflamme et al., 2011; Tarhan et al., 2010), 
345 Conichnus trace-makers may have been able to exploit these environments relatively free

346 of competition from established Ediacaran tiered communities. In these settings, the

347 increased current velocities may have prevented cohesive mat formation (facilitating

348 anchoring and mobility in the substrate), and guaranteed a ready supply of suspended

349 organic particles and/or prey organisms.

350 This model has some support from other Ediacaran localities. Metazoan trace

351 fossils occur most frequently as isolated monospecific assemblages lacking Ediacara

352 biota (although occasionally with the infaunal and problematic taxon Nilpenia - Droser et

353 al., 2013) suggesting that niche partitioning between these two organismal groups

354 extends back at least until the mid-Ediacaran. Typical exclusivity between Ediacara biota

355 and metazoan trace fossils is supported both in older sections from Mistaken Point in

356 Newfoundland, Canada (Liu et al., 2010; 2014), and in late Ediacaran trace fossil

357 assemblages lacking Ediacaran macrofossils altogether (Pecoits et al., 2012). Some rare

358 exceptions to this rule are known, including the probable mollusk Kimberella, which is

359 often found within diverse communities of more enigmatic Ediacaran organisms, or the

360 lowermost Cambrian association between Erniettomorph-like fronds and complex trace

361 fossils (including Treptichnus pedum) described by Jensen et al. (1998) from south

362 Australia. This may indicate that direct interactions between Ediacaran- and Cambrian-

363 type organisms only really became common following the Ediacaran-Cambrian

364 transition, when it may have been forced by the rapid diversification of animal groups

365 and expansion into new ecospace. 
368 replacement model for the Ediacaran-Cambrian transition suggests that early members

369 (or precursors) of the Cambrian evolutionary fauna gradually displaced Ediacaran biotas

370 through a combination of predatory displacement and ecological engineering of

371 Ediacaran-type ecosystems (Laflamme et al., 2013, Darroch et al., 2015; Schiffbauer et

372 al., in press; see also Seilacher, 1992; Bengston and Yue, 1992; Hua et al., 2003). These

373 new fossil localities support the inference of both stratigraphic and ecological overlap

374 between these two organismal groups, and so fulfills a fundamental prediction of the

375 model. However, evidence for direct biotic interactions between soft-bodied Ediacara

376 biota and Cambrian-style metazoans (and thus providing concrete mechanisms for 'biotic

377 replacement') is still sparse. For example, there is no evidence as yet for predation on

378 soft-bodied Ediacaran organisms. The high frequency of drill holes in Cloudina from

379 latest Ediacaran reefs (Hua et al., 2003) certainly indicates that metazoan predation had

380 emerged as an ecological strategy for nutrient acquisition, however, Cloudina (and other

381 biomineralizing taxa such as Namacalathus) are more commonly thought of as

382 metazoans (Wood and Curtis, 2015; Wood et al., 2015; Schiffbauer et al., in press). As

383 such, evidence for wide-spread predatory activities on soft-bodied sessile Ediacarans is

384 still lacking. Interpretation of Conichnus burrows as being produced by anthozoan

385 cnidarians (e.g., Frey and Howard, 1981; Bromley, 1996; Abad et al., 2006; Buatois et

386 al., 2014; Desai and Saklani, 2015) does offer a possible mechanism - all anthozoans are

387 predatory (using nematocyst stinging cells), and most likely evolved as predators adapted

388 to catching and digesting relatively large prey items via either filter feeding or passive

389 predation (Hand, 1963). In the event that representatives of the Ediacara biota possessed 
390 a mobile larval or dispersal stage early in development (Clapham et al., 2003; Darroch et

391 al., 2013; Wood and Curtis, 2014), it is conceivable that these may have been prey for

392 emerging Cambrian-type predatory and/or filter-feeding animals. However, in the

393 absence of anthozoan body fossils the Conichnus trace fossil-trace maker link remains

394 unproven, and a model of Ediacaran passive predation by anthozoans must be viewed as

395 speculative.

396 The evidence for increasing ecosystem engineering in the latest Ediacaran is more

397 compelling. Although 'ecosystem engineering' refers to a variety of trophic and non-

398 trophic biological processes (Erwin and Tweedt, 2011), it is most commonly preserved in

399 the rock record as trace fossils showing vertical disruption of the sediment column and

400 sediment-water interface. Recent work in the Nama Group has uncovered a suite of trace

401 fossils with far higher diversity than any of those recorded for older Ediacaran settings,

402 including Conichnus, Strepichnus narbonnei, Olenichnus (Jensen and Runnegar, 2005),

403 Nereites (Bouougri et al., 2007), and a horizontal feeding burrow resembling Zoophycus

404 (Mcdonald et al., 2014). These discoveries provide clear evidence for an increasing

405 diversity and intensity of metazoan activity, which likely had a profound effect on

406 Ediacaran ecosystems (Laflamme et al., 2013; Erwin and Valentine, 2013). Impacts

407 likely included (but were not limited to) changes in the oxygenation state of the oceans,

408 the distribution of nutrients in the water column, and the stability of benthic substrates

409 (Erwin and Tweedt, 2011). This inference matches well with the appearance of metazoan

410 and filter-feeding reef builders, which show evidence for episodes of pulsed recruitment

411 and philopatric larval aggregation (Wood and Curtis, 2014). Taken together, these lines

412 of evidence illustrate a pronounced change in the character and volume of suspended 
413 particulate organic matter (and potentially zooplankton - see Butterfield, 2009) from

414 earlier in the Ediacaran, and suggest an oceanic ecosystem that differs dramatically from

415 the older Ediacaran successions preserved in South Australia and Russia.

\section{Conclusions}

The new fossil localities described here extend the known geographic range of

420 soft-bodied Ediacara biota to include the Zaris sub-basin of southern Namibia. The co-

421 occurrence of soft-bodied Ediacara biota and metazoan trace fossils supports inference of

422 unusual latest Ediacaran shallow-water ecosystems comprising two very different

423 branches of eukaryotic life. Although the precise nature of biotic interactions between

424 Ediacarans and metazoans is still unclear, these new localities indicate stratigraphic and

425 ecological overlap between these two organismal groups, and so fulfills a fundamental

426 prediction of the biotic replacement model. Preliminary observations of a mutual

427 exclusivity between frondose Ediacara biota and metazoan trace fossils in these new

428 localities may suggest a form of niche partitioning, and thus inference of limited direct

429 biotic interactions between these two organismal groups. Although the data supporting

430 this are currently limited, and we cannot as yet test the significance of these associations

431 with any statistical power, they do help form a hypothesis that can be tested with future

432 fossil discoveries.

\section{Acknowledgements}


436 We extend thanks to the Geological Survey of Namibia, and in particular Helke Mocke,

437 Charlie Hoffmann, Roger Swart, and Gabi Schneider for logistical help in conducting

438 fieldwork. S.A.F.D. and R.A.R. thank the Yale Peabody Museum of Natural History for

439 generous financial support. R.A.R. is currently funded by NSF grants DEB 1331980 and

440 PLR 134175 to N. Smith. M.L., S.T., and D.H.E. thank the NASA Astrobiology Institute;

441 M.L. and T.H.B. thank the Connaught Foundation, National Science and Engineering

442 Research Council of Canada, and National Geographic Society for generous funding. We

443 also thank Luis Buatois, Gabriela Mangano, and Lidya Tarhan for constructive criticism,

444 and Rachel Jongsma for assistance in the field.

445

446 References

447

448 Abad, M., Ruiz, F., Pendón, J.G., Tosquella, J., González-Regalado, M.L., 2006, Escape

449 and equilibrium trace fossils in association with Conichnus conicus as indicators of

450 variable sedimentation rates in Tortonian littoral environments of SW Spain:

$451 \quad$ Geobios, v. 39, p. 1-11.

452 Bengtson, S., and Yue, Z., 1992, Predatorial borings in Late Precambrian mineralized

453 exoskeletons: Science, v. 257, p. 367-369.

454 Billings, E. 1872. Fossils in Huronian rocks. Canadian Naturalist and Quarterly Journal $455 \quad$ of Science 6: 478.

456 Boag, T.H., Darroch, S.A.F., and Laflamme, M., Ediacaran distributions in space and 457 time: testing assemblage concepts of earliest macroscopic body fossils: Paleobiology, $458 \quad$ published online $25^{\text {th }}$ May 2016. 
459 Brasier, M., Cowie, J., and Taylor, M., 1994, Decision on the Precambrian-Cambrian

460 boundary stratotype: Episodes, v. 17, p. 3-8.

461 Bromley R.G., 1996. Trace fossils: biology, taphonomy and applications: Chapman \& 462 Hall, London.

463 Buatois, L.A, Narbonne, G.M., Mangano M.G., Carmona, N.B., and Myrow, P., 2014,

464 Ediacaran matground ecology persisted into the earliest Cambrian: Nature

465 Communications, v. 5, p. 35-44.

466 Buatois, L.A., and Mángano, M.G., 2011, Ichnology: Organism-Substrate Interactions in $467 \quad$ Space and Time: Cambridge University Press.

468 Burzynski, G., and Narbonne, G.M., 2015. The discs of Avalon: Relating discoid fossils

469 to frondose forms in the Ediacaran of Newfoundland, Canada. Palaeogeography

$470 \quad$ Palaeoclimatology, Palaeoecology v. 434, p. 34- 45.

471 Butterfield, N.J., 2007, Macroecology and macroevolution through deep time:

472 Palaeontology, v. 50, p. 41-55.

473 Butterfield, N.J., 2009, Oxygen, animals and oceanic ventilation: an alternative view:

$474 \quad$ Geobiology, v. 7, p. 1-7.

475 Cai, Y., and Hua, H., 2011, Discussion of 'First finds of problematic Ediacaran fossil

476 Gaojiashania in Siberia and its origin': Geological Magazine, v. 148, p. 329-333.

477 Cai, Y., Schiffbauer, J.D., Hua, H., and Xiao, S., 2011, Morphology and paleoecology of 478 the late Ediacaran tubular fossil Conotubus hemiannulatus from the Gaojiashan 479 Lagerstatte of southern Shaanxi Province, South China: Precambrian Research, v. $480 \quad 191$, p. $46-57$. 
481 Carbone, C., and Narbonne, G.M., 2014, When life got smart: the evolution of behavioral 482 complexity through the Ediacaran and Cambrian of NW Canada: Journal of 483 Paleontology, v. 88, p. 309-330.

484 Cohen, P.A., Bradley, A., Knoll, A.H., Grotzinger, J.P., Jensen, S., Abelson, J., Hand, K., 485 Love, G., Metz, J., McLoughlin, N., Meister, P., Shepard, R., Tice, M., and Wilson, 486 J.P., 2009, Tubular compression fossils from the Ediacaran Nama Group, Namibia: 487 Journal of Paleontology, v. 83, p. 110-122.

488 Curran, H.A., 2007, Ichnofacies, ichnocoenoses, and ichnofabrics of Quaternary shallow489 marine to dunal tropical carbonates: a model and implications, in Miller III, W., ed., 490 Trace Fossils: Concepts, Problems and Applications. Elsevier: Amsterdam.

491 Darroch, S.A.F., Laflamme, M., and Clapham M.E., 2013, Population structure of the 492 oldest known macroscopic communities from Mistaken Point, Newfoundland: $493 \quad$ Paleobiology, v. 39, p. 591-608.

494 Darroch, S.A.F., Sperling, E.A., Boag, T., Racicot, R.A., Mason, S.J., Morgan, A.S., 495 Tweedt, S., Myrow, P., Johnston, D.T., Erwin, D.H., and Laflamme, M., 2015, Biotic 496 replacement and the first mass extinction of complex life: Proceedings of the Royal 497 Society B, v. 282, 20151003.

498 Desai, B.G., and Saklani, R.D., 2015, Palaeocommunity dynamics and behavioral 499 analysis of Conichnus: Bhuj Formation (Lower Cretaceous), Kachchh-India: Ichnos $500 \quad$ v. 22, p. $43-55$.

501 Droser, M.L, and Gehling, J.G., 2008, Synchronous aggregate growth in an abundant new 502 Ediacaran tubular organism: Science, v. 319, p. 1660-1662. 
503 Droser, M.L., Gehling, J.G., and Jensen, S.R., 2006, Assemblage palaeoecology of the

504 Ediacara biota: the unabridged edition?: Palaeogeography, Palaeoclimatology,

505 Palaeoecology v. 232, p. 131-147.

506 early history of animals: Science, v. 334, p. 1091-1097.

507 Erwin, D.H., Laflamme, M., Tweedt, S.M., Sperling, E.A., Pisani, D., and Peterson, K.J.,

508 2011, The Cambrian conundrum: early divergence and later ecological success in the

509 Erwin, D.H., and Tweedt, S.M., 2011, Ecological drivers of the Ediacaran-Cambrian

510 diversification of Metazoa: Evolutionary Ecology v. 26, p. 417-433.

511 Erwin, D.H., and Valentine, J.W., 2013, The Cambrian Explosion: The Construction of

512 Animal Biodiversity: Roberts Publishers,

513 Frey, R.W., and Howard, J.D., 1981, Conichnus and Schaubcylindrichnus: redefined

514 trace fossils from the Upper Cretaceous of the Western Interior: Journal of

515 Paleontology, v. 55, p. 800-804.

516 Frey, S.E., Gingras, M.K., and Dashtgard, S.E., 2009, Experimental studies of gas-escape

517 and water-escape strcutures: mechanisms and morphologies: Journal of Sedimentary

518 research, v. 79, p. 808-816.

519 Gehling, J.G. and Narbonne, G.M., 2007, Spindle-shaped Ediacara fossils from the

520 Mistaken Point assemblage, Avalon Zone, Newfoundland: Canadian Journal of Earth

$521 \quad$ Sciences, v. 44, p. 367-387.

522 Germs, G.J.B., 1983, Implications of a sedimentary facies and depositional

523 environmental analysis of the Nama Group in Southwest Africa/Namibia, in Miller, 
524 R.McG., ed., Evolution of the Damara Orogen: Geological Society of South Africa, 525 Special Publication, v. 11, p. 89-114.

526 Geyer, G., 2005, The Fish River Subgroup in Namibia: stratigraphy, depositional

527 environments and the Proterozoic-Cambrian boundary problem revisited: Geological

$528 \quad$ Magazine v. 142, p. 465-498.

529 Gingras, M.K., Dashtgard, S.E., MacEachern, J.A., and Pemberton, S.G., 2008, Biology

530 of shallow marine ichnology: a modern perspective: Aquatic Biology, v. 2, p. 255531268.

532 Grotzinger, J.P., Bowring, B.Z., Saylor, B.Z., and Kaufman, A.J., 1995, Biostratigraphic 533 and geochronologic constraints on early animal evolution: Science, v. 270, p. 598534604.

535 Grotzinger, J.P., Watters, W.A., and Knoll, A.H., 2000, Calcified metazoans in 536 thrombolite-stromatolite reefs of the terminal Proterozoic Nama Group, Namibia:

537 Paleobiology, v. 26, p. 334-359.

538 Gürich, G. 1930. Die bislang ältesten Spuren von Organismen in Südafrika. International 539 Geological Congress. South Africa, 1929 (XV) 2: 670-680.

540 Hagadorn, J.W., and Waggoner, B., 2000, Ediacaran fossils from the southwestern Great 541 Basin, United States: Journal of Paleontology, v. 74, p. 349-359.

542 Hand, C., 1963, The Early Worm: A Planula, in Dougherty, E.C., Brown, N., Hanson, 543 E.D., and Hartman, W.D., eds., The Lower Metazoa: Comparative Biology and $544 \quad$ Phylogeny: University of California Press. 
545 Hou, X-G, Stanley, G., Zhao, J., and Ma, X-Y., 2005, Cambrian anemones with

546 preserved soft tissue from the Chengjiang biota, China: Lethaia, v. 38, p. 193-203.

547 Hua, H., Pratt, B.R., and Zhang, L.-Y., 2003, Borings in Cloudina shells: complex

548 predator-prey dynamics in the terminal Neoproterozoic: Palaios, v. 18, p. 454-459.

549 Hua, H., Chen, Z., Yuan, X., Zhang, L., and Xiao, S., 2005, Skeletogenesis and asexual

550 reproduction in the earliest biomineralizing animal Cloudina: Geology, v. 33, p. 277-

551280.

552 Jensen, S., and Runnegar, B.N., 2005, A complex trace fossil from the Spitskop Member

553 (terminal Ediacaran-? Lower Cambrian) of southern Namibia: Geological Magazine

$554 \quad$ v. 142 , p. $561-569$.

555 Jensen, S., Gehling, J.G., and Droser, M.L., 1998, Ediacara-type fossils in Cambrian

556 sediments: Nature, v. 393, p. 567-569.

557 Laflamme, M., and Narbonne, G.M., 2008, Ediacaran fronds: Palaeogeography

558 Palaeoclimatology Palaeoecology, v. 258, p. 162-179.

559 Laflamme, M., Schiffbauer, J.D., Narbonne, G.M., and Briggs, D.E.G., 2011, Microbial

560 biofilms and the preservation of the Ediacara biota. Lethaia, v. 44, p. 203-213.

561 Laflamme, M., Darroch, S.A.F., Tweedt, S., Peterson, K.J., and Erwin, D.H., 2013, The

562 end of the Ediacara biota: extinction, biotic replacement, or Cheshire Cat?:

563 Gondwana Research v. 23, p. 558-573.

564 Lin, S., Zhang, Y., Zhang, L., Tao, X., and Wang, M., 1986. Body and trace fossils of

565 metazoa and algal macrofossils from the upper Sinian Gaojiashan Formation in

566 southern Shaanxi. Geology of Shaanxi 4, 9-17 (in Chinese with English abstract). 
568 Liu, A.G., McIlroy, D., Matthews, J.J., and Brasier, M.D., 2014, Confirming the

569 metazoan character of a 565 Ma trace-fossil assemblage from mistaken Point,

$570 \quad$ Newfoundland: Palaios, v. 29, p. 420-430.

571 Macdonald, F.A., Pruss, S.B., and Strauss, J.V., 2014, Trace fossils with spreiten from

572 the late Ediacaran Nama Group, Namibia: complex feeding patterns five million years

573 before the Precambrian-Cambrian boundary. Journal of Paleontology, v. 88, p. 299574308.

575 Mata, S.A., Corsetti, C.L., Corsetti, F.A., Awramik, S.M., and Bottjer, D.J., 2012, Lower

576 Cambrian anemone burrows from the Upper Member of the Wood Canyon

577 Formation, Death Valley Region, United States: paleoecological and

578 palaeoenvironmental significance: Palaios, v. 27, p. 594-606.

579 McIlroy, D., Crimes, T.P. and Pauley, J.C., 2005, Fossils and matgrounds from the

580 Neoproterozoic Longmyndian Supergroup, Shropshire, UK. Geological Magazine, v. $581 \quad 142$, p. 441-455.

582 Menon, L.R., McIlroy, D., and Brasier, M.D., 2013, Evidence for Cnidaria-like behavior 583 in ca. 560 Ma Ediacaran Aspidella: Geology, v. 41, p. 895-899.

584 Menon, L.R., McIlroy, D., Liu, A.G. and Brasier, M.D., 2016, The dynamic influence of 585 microbial mats on sediments: fluid escape and pseudofossil formation in the 586 Ediacaran Longmyndian Supergroup, UK. Journal of the Geological Society, v. 173, 587 p. 177-185. 
588 Meyer, M., Schiffbauer, J.D., Xiao, S., Cai, Y., and Hua, H., 2012, Taphonomy of the

589 upper Ediacaran enigmatic ribbonlike trace fossil Shaanxilithes: Palaios, v. 27, p.

$590 \quad 354-372$.

591 Murchison, R.I., 1839, The Silurian System. John Murray, London, 768 p.

592 Myannil, R.M., 1966, O vertikalnykh norkakh zaryvaniya v Ordovikskikh izvestiyakakh

593 Pribal-tiki (A small vertically excavated cavity in Baltic Ordovician limestone).

594 Akad. Nauk SSSR, Paleont. Inst., p. 200-207.

595 Narbonne, G.M., Myrow, P.M., Landing, E., and Anderson, M.M., 1987, A candidate

596 stratotype for the Precambrian-Cambrian boundary, Fortune Head, Burin Peninsula,

597 southeastern Newfoundland: Canadian Journal of Earth Sciences, v. 24, p. 1277-

$598 \quad 1293$.

599 Narbonne, G.M., Saylor, B.Z., and Grotzinger, J.P., 1997, The youngest Ediacaran fossils

600 from Southern Africa. Journal of Palaeontology 71, 953-967.

601 Narbonne, G.M., 2005, The Ediacara biota: Neoproterozoic origin of animals and their

602 ecosystems: Annual Reviews of Earth and Planetary Sciences, v. 33, p. 421-442.

603 Nichols, R.A., Sparks, S.J., and Wilson, C.J.N., 1994, Experimental studies of the

604 fluidization of layered sediments and the formation of fluid escape structures:

605 Sedimentology, v. 41, p. 233-253.

606 Park, E., Hwang, D.S., Lee, J.S., Seo, T.K., and Won, Y.J., 2012, Estimation of

607 divergence times in cnidarian evolution based on mitochondrial protein-coding genes

608 and the fossil record. Molecular Phylogenetics and Evolution, v. 62, p. 329-345. 
609 Penny, A.M., Wood, R., Curtis, A., Bowyer, F., Tostevin, R., and Hoffman, K-H., 2014,

610 Ediacaran metazoan reefs from the Nama Group, Namibia: Science, v. 334, p. 1504$611 \quad 1506$.

612 Pflug, H.D. 1972a. Zur fauna der Nama-Schichten in Sudwest Afrika. I. Pteridinia, Bau 613 und systematische Zugehorikeit. Palaeontographica Abteilung A 143: 226-262.

614 Prantl, F. 1946: Dve zahadne zkameneliny (stopy) z vrstev chrustenickych- dB3.

615 Rozpravy Ceske Akademie Ved a Umeni, Tfida Il, 55:3, 1-18.

616 Rodgers, A.D., 2009, Cnidarians (Cnidaria), in Blair Hedges, S.B., and Kumar, S., eds., 617 The Timetree of Life: Oxford University Press.

618 Sappenfield, A., Droser, M.L., and Gehling, J.G., 2011, Problematica, trace fossils, and 619 tubes within the Ediacara member (South Australia): redefining the Ediacaran trace 620 fossil record one tube at a time: Journal of Paleontology, v. 85, p. 256-265.

621 Saylor, B.Z., Kaufman, A.J., Grotzinger, J.P., and Urban, F., 1998, A composite 622 reference section for terminal Proterozoic strata of southern Namibia: Journal of 623 Sedimentary Research, v. 68, p. 1223-1235.

624 Schiffbauer, J.D., Huntley, J.W., O’Neil, G.R., Darroch, S.A.F., Laflamme, M., Cai, Y. 625 In press. The Rise of Animals: Neither Cambrian nor Explosive. GSA Today.

626 Seilacher, A.,1992, Vendobionta and Psammocorallia: lost constructions of Precambrian 627 evolution: Geological Society of London, Special Publications, v. 149, p. 607-613.

628 Tarhan, L.G., Droser, M.L., and Gehling, J.G., 2010, Taphonomic Controls on Ediacaran 629 Diversity: Uncovering the Holdfast Origin of Morphologically Variable Enigmatic 630 Structures: Palaios, v. 25, p. 823-830. 
$632 \quad 6$, Afd 2:8, 1-14.

633 Vickers-Rich, P., Ivantsov, A.Y., Trusler, P.W., Narbonne, G.M., Hall, M., Wilson, S.A.,

634 Greentree, C., Fedonkin, M., Elliot, D., Hoffmann, K., and Schneider, G., 2013,

635 Reconstructing Rangea: new discoveries from the Ediacaran of southern Namibia:

636 Journal of Paleontology, v. 87, p. 1-15.

637 Wood, R. and Curtis, A., 2014, Extensive metazoan reefs from the Ediacaran Nama

638 Group: the rise of benthic suspension feeding: Geobiology. Article published online.

639 DOI: $10.1111 /$ gbi.12122

640 Xiao, S., and Laflamme, M., 2009, On the eve of animal radiation: phylogeny, ecology,

641 and evolution of the Ediacara biota: Trends in Ecology \& Evolution v. 24, p. 31-40.

642 Xing, Y., D, Q.,ing Luo, H., He, T., and Wang, Y., 1984, The Sinian-Cambrian

643 Boundary of China. Bulletin of the Institute of Geology, Chinese Academy of

644 Geological Sciences no. 10, 1-262 (in Chinese with English summary).

645

646 Figure and table captions

647

648 Figure 1 - Locality figure, illustrating: a) the distribution of Nama Group sediments in

649 southwest Africa. b) The distribution of new fossil sites along the D850 and D855 roads,

650 in the vicinity of Zebra River Farm. c) Generalized stratigraphy of the Zaris sub-basin in

651 the vicinity of Zebra River, and approximate position of fossil sites described in this

652 study; section logs are given for the two sites where both Aspidella fossils and Conichnus 
653 burrows were recovered in-situ. Base map in a) and regional $\log$ section in c) redrawn

654 from Grotzinger et al. (2000).

655

656 Figure 2 - Ediacara biota and trace fossils recovered from new fossil sites in the

657 Schwarzrand subgroup: a-b) Aspidella; c-d) Shaanxilithes cf. ninqiangensis preserved in

658 three dimensions; e-i) Conichnus sp. trace fossils preserved on collected slabs. Note that

$659 \mathrm{e}, \mathrm{f}$, and $\mathrm{h}$ illustrate preservation in positive epirelief on slab topsurfaces, while $\mathrm{g}$

660 illustrates 'dimple' shaped morphology on bottom surfaces (negative hyporelief with

661 positive hyporelief in center). Filled scale bars $1 \mathrm{~cm}$; open scale bars $1 \mathrm{~mm}$.

662

663 Figure 3 - Exceptional part and counterpart preservation in Aspidella collected from

664 locality S.04. Also note presence of MISS on same slab. Scale bars in $\mathrm{cm}$.

665

666 Figure 4 - Large Aspidella (negative epirelief) collected from locality S.015. Highlighted

667 areas show examples of (b) radiating and 'tentaculate' structures present around several

668 of the holdfasts, and (c) variable morphology of holdfast 'plugs', suggesting preservation

669 in a variety of localized taphonomic styles. Holdfast size-frequency (diameter, n=15) and

670 cluster analysis plots are shown in d); wide range of holdfast sizes suggests a mature

671 stand of frondose Ediacaran taxa in a late stage of ecological succession. Size frequency

672 plot suggests a bimodal distribution of holdfast sizes, likely representing two separate age

673 classes (cohorts) in the frond population. Scale bars represent $1 \mathrm{~cm}$ increments. 
675 Figure 5 - Polished sections through Conichnus traces illustrating internal features: a)

676 two closely associated vertical burrows (arrowed) clearly cutting through laminae (' $\operatorname{Tr}$ '),

677 and showing gross morphology with domed topsurfaces (positive epirelief, 'Do') and

678 'dimple'-shaped morphologies ('Di') on the bottom surfaces (hyporelief). Note that

679 burrows do not show any tendency to join as a 'u-bend'. b) and c) show enlarged views

680 of the same traces, illustrating both sharp (white arrow) and diffuse (black arrow)

681 interfaces between matrix and burrow fill. The differences between more homogenous

682 sediment (although preserving faint traces of cone-in-cone structure) inside burrows

683 ('Hs') and undisrupted/laminated sediment in matrix ('Ls') are also clear. d) and e) show

684 two different burrows possessing the same characteristics as those figured in a-c), note

685 shallow meniscate (cone-in-cone) infill to burrows and thin mud drapes ('Md') that

686 deflect up into burrow margins, indicating upwards movement of the tracemaker during

687 life. Scale bars $1 \mathrm{~mm}$.

688

689 Figure 6 - Shaanxilithes cf. ningqiangensis from locality S.015, with tube diameter

690 measurements and comparison (e) with the morphologically similar taxon Gaojiashania

691 (diameter range data from Cai et al., 2011). White arrows indicate in-place holdfast

692 structures, illustrating that Shaanxilithes lived in close association with frondose

693 Ediacaran taxa. Black arrows indicate instances of tight coiling, suggesting that tubes

694 were likely flexible in life. Black arrow with white border in d indicates an example of

695 where discs have 'slipped', possibly post-mortem and after degradation of tube walls.

696 Scale bars represent $1 \mathrm{~cm}$ increments. 
698 Table 1 - Details of collected fossil material, lithology and presence/absence of trace

699 fossils for new fossil localities from the Schwarzrand Subgroup, southern Namibia (see

700 also Fig. 1). All collected specimens are accessioned in the Geological Survey of

701 Namibia, Windhoek. 


\begin{tabular}{|c|c|c|c|c|}
\hline $\begin{array}{l}\text { Site } \\
\text { ID }\end{array}$ & Fossils & Sample no. & $\begin{array}{l}\text { Lithology \& } \\
\text { sedimentology }\end{array}$ & Notes \\
\hline S.01 & Erniettomorph & S.01(1) & $\begin{array}{l}\text { Thin-bedded } \\
\text { siltstones and } \\
\text { shales } w \text {. occ. } \\
\text { rippled horizons }\end{array}$ & $\begin{array}{l}\text { Abundant MISS on loose slabs; } \\
\text { also rare flute casts }\end{array}$ \\
\hline S.04 & Aspidella & S.04(1) & $\begin{array}{l}\text { Thin-bedded } \\
\text { siltstones and } \\
\text { shales w. occ. } \\
\text { rippled horizons }\end{array}$ & $\begin{array}{l}\text { Trio of Aspidella preserved w. } \\
\text { MISS }\end{array}$ \\
\hline S.011 & Aspidella & S.011(1-2) & $\begin{array}{l}\text { Laminated } \\
\text { siltstones and } \\
\text { shales }\end{array}$ & Abundant MISS \\
\hline S.014 & Aspidella & S.014(1) & $\begin{array}{l}\text { Thin-bedded } \\
\text { siltstones w. occ. } \\
\text { rippled horizons }\end{array}$ & In-situ outcrop \\
\hline S.015 & $\begin{array}{l}\text { Shaanxilithes; } \\
\text { Aspidella } \\
\text { (Hiemalora?) } \\
\text { Bergaueria }\end{array}$ & S.015(5-12) & 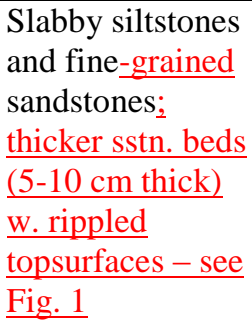 & $\begin{array}{l}\text { Conichnus sp. common on slab } \\
\text { topsurfaces }\end{array}$ \\
\hline S.018 & Aspidella & NA & $\begin{array}{l}\text { Siltstones W. occ. } \\
\text { rippled horizons }\end{array}$ & In-situ outcrop \\
\hline S.019 & Aspidella & NA & $\begin{array}{l}\text { Silstones and } \\
\text { fine sandstones; } \\
\text { thicker sstn. beds } \\
\text { W. rippled } \\
\text { topsurfaces - see } \\
\text { Fig. 1 }\end{array}$ & $\begin{array}{l}\text { Riverbed section w. in-situ } \\
\text { outcrop \& Conichnus - see Fig. } 1\end{array}$ \\
\hline
\end{tabular}

2

3 Table 1 


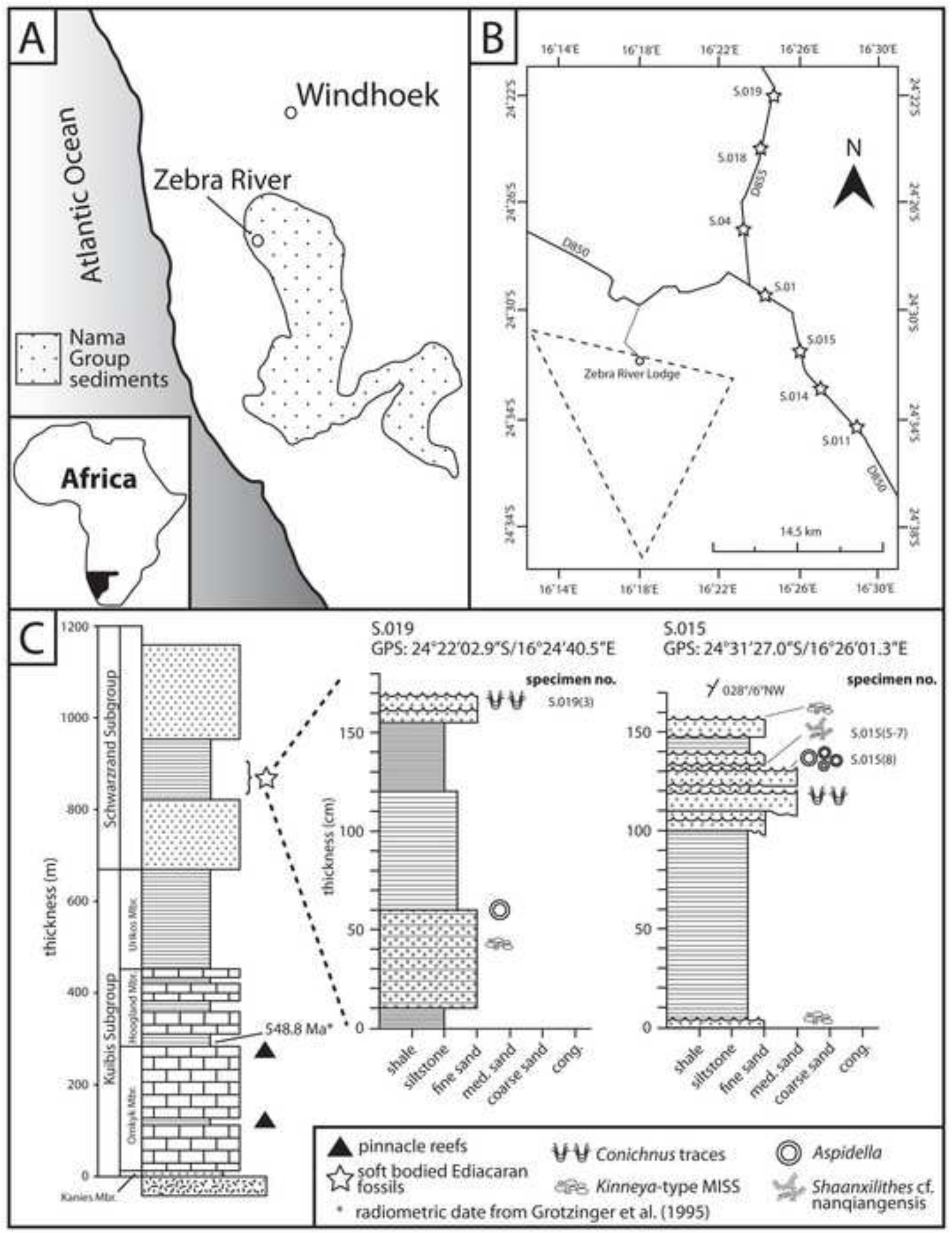



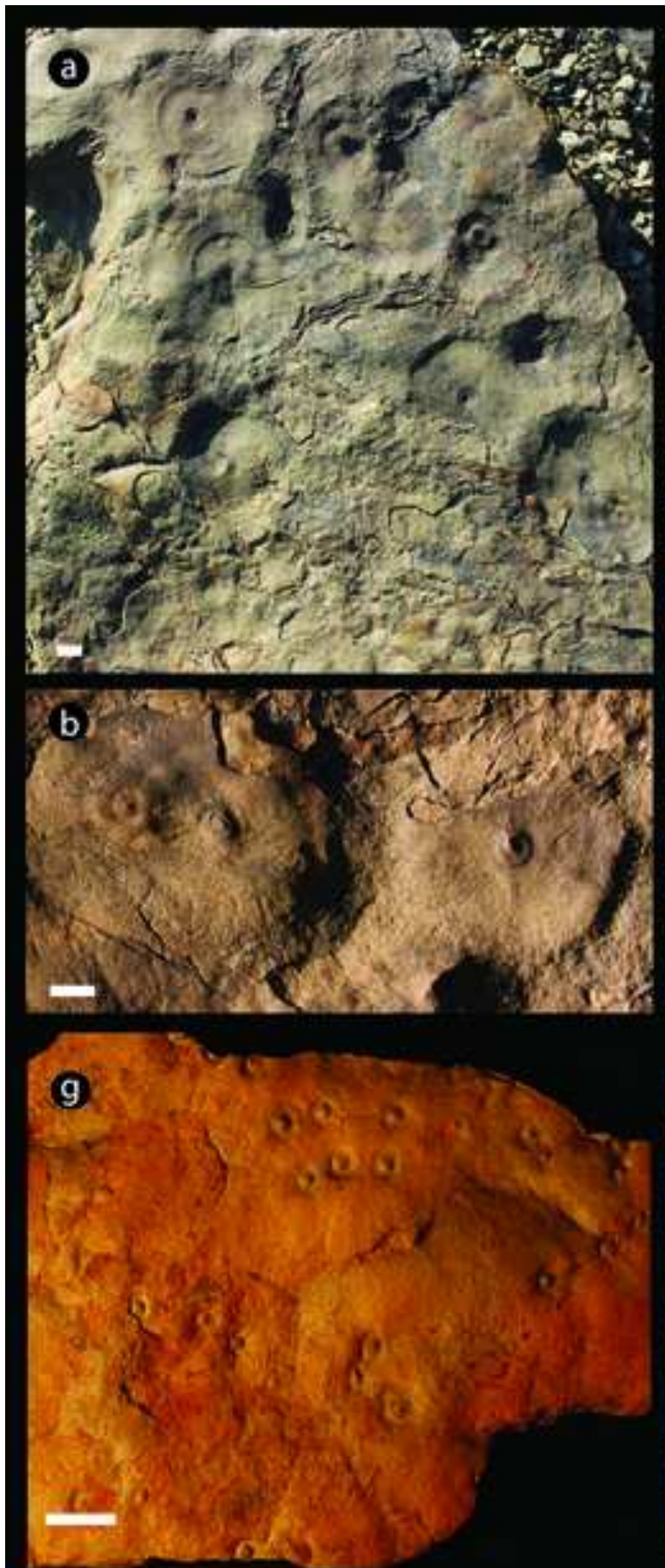

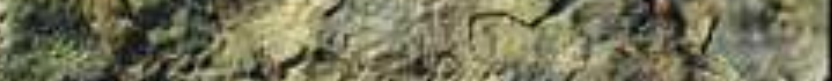

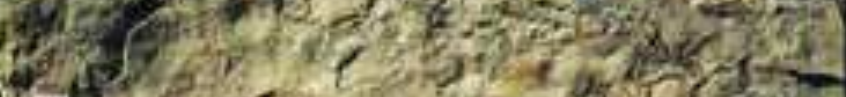

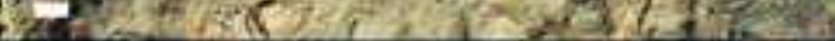
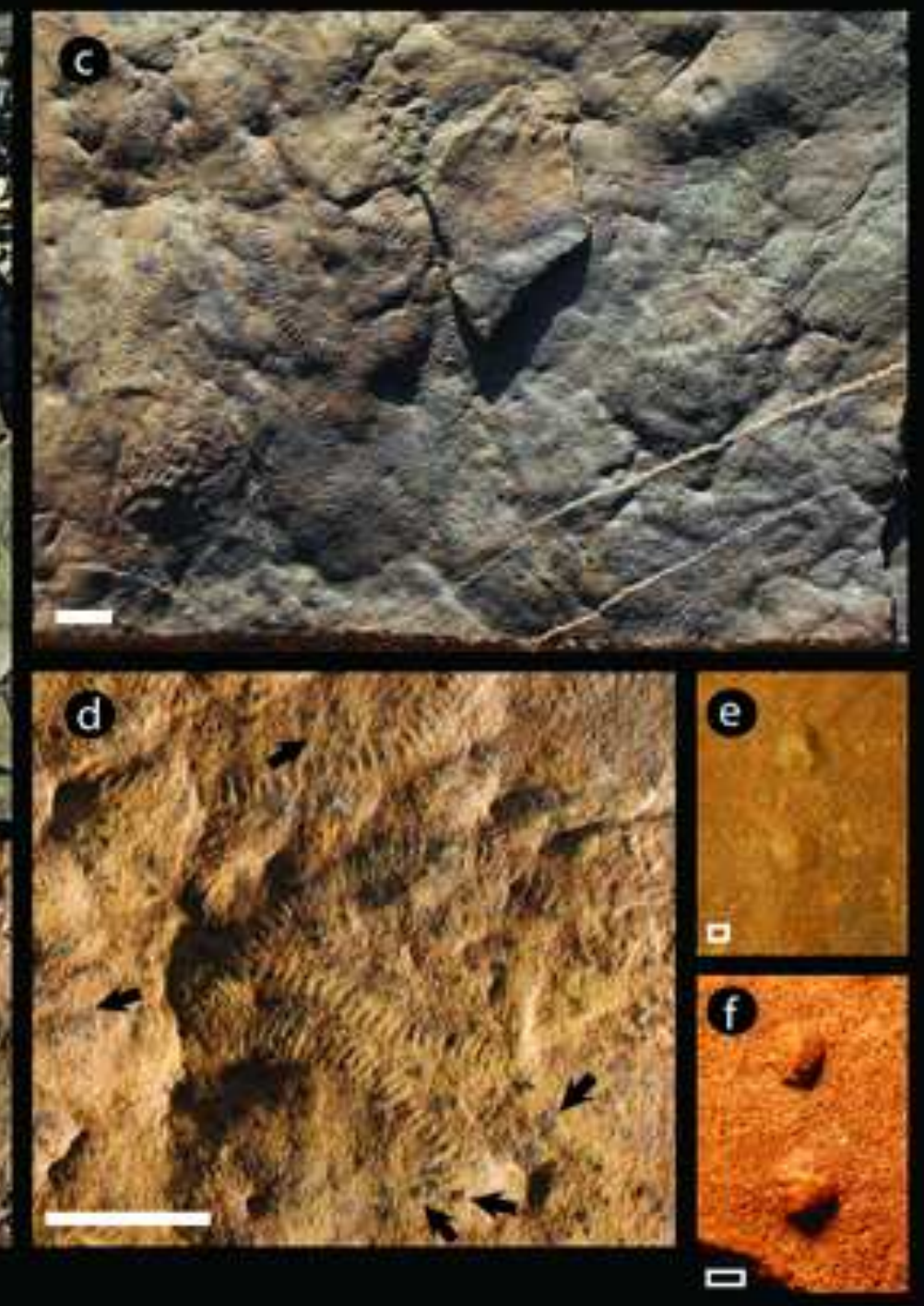

e

$=$

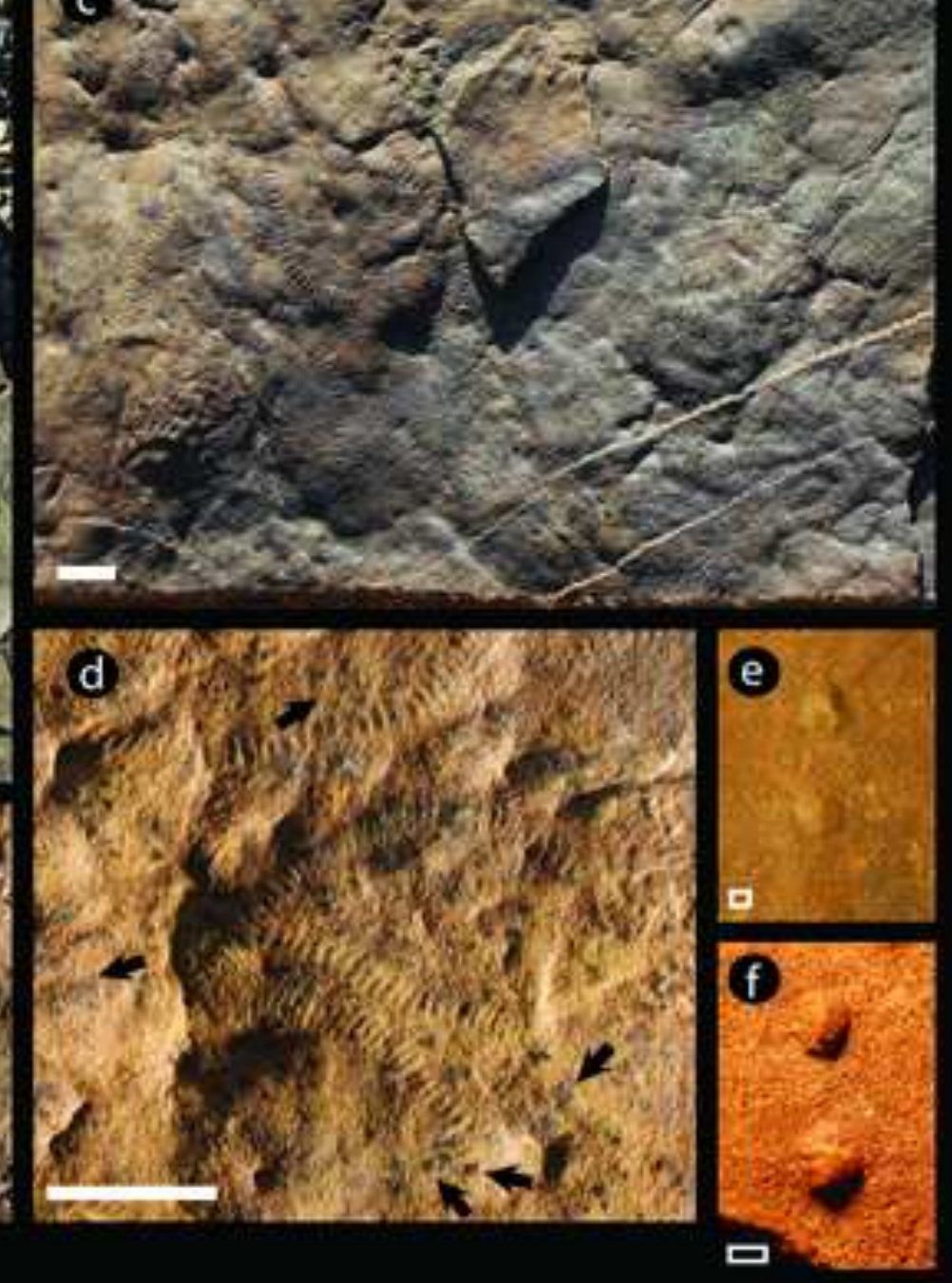

h

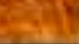



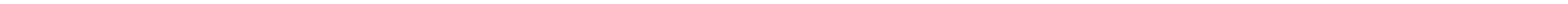

$$
\text { te }
$$




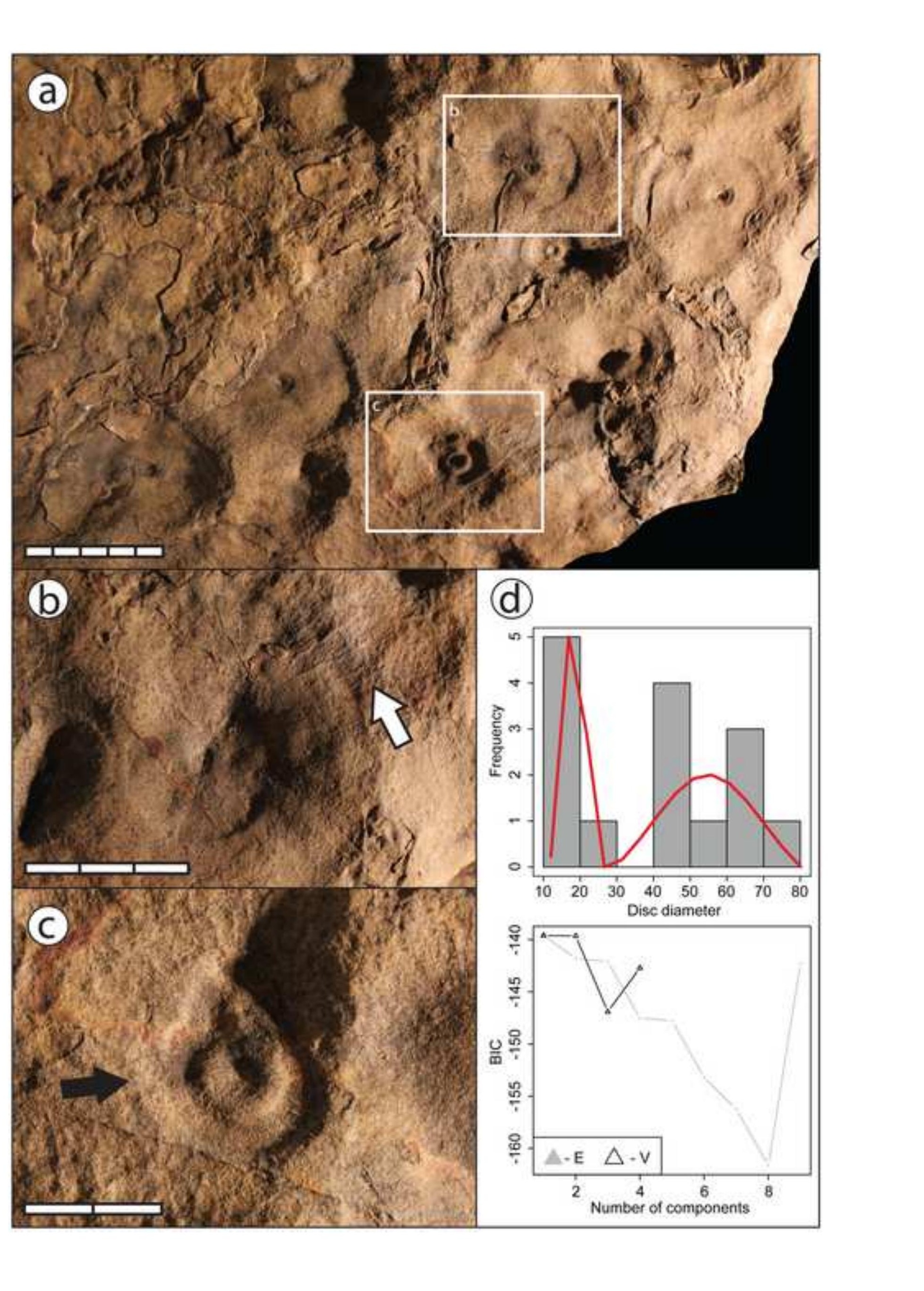

\section{.}

.




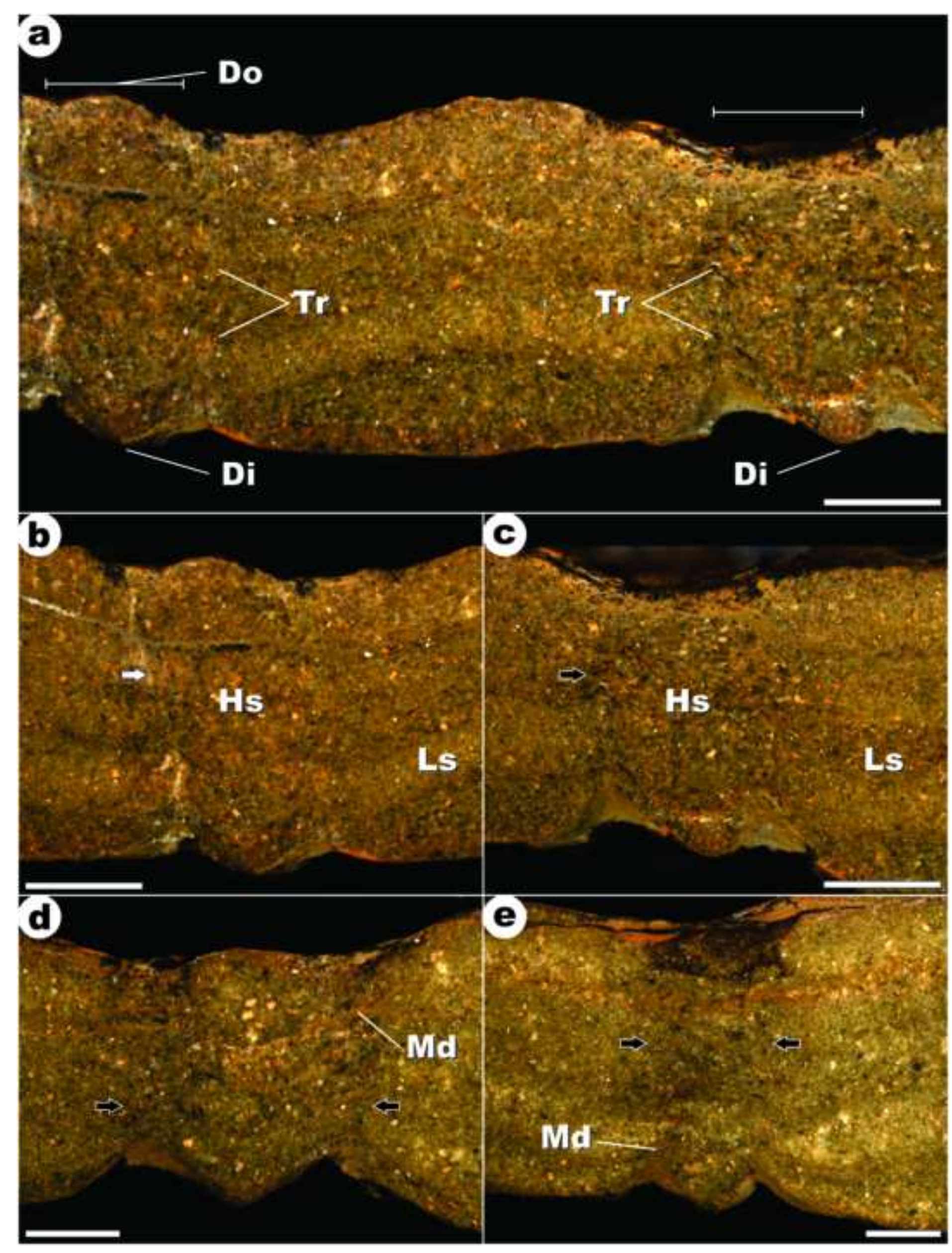

Figure 5

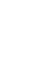

\section{.} . .

. . 


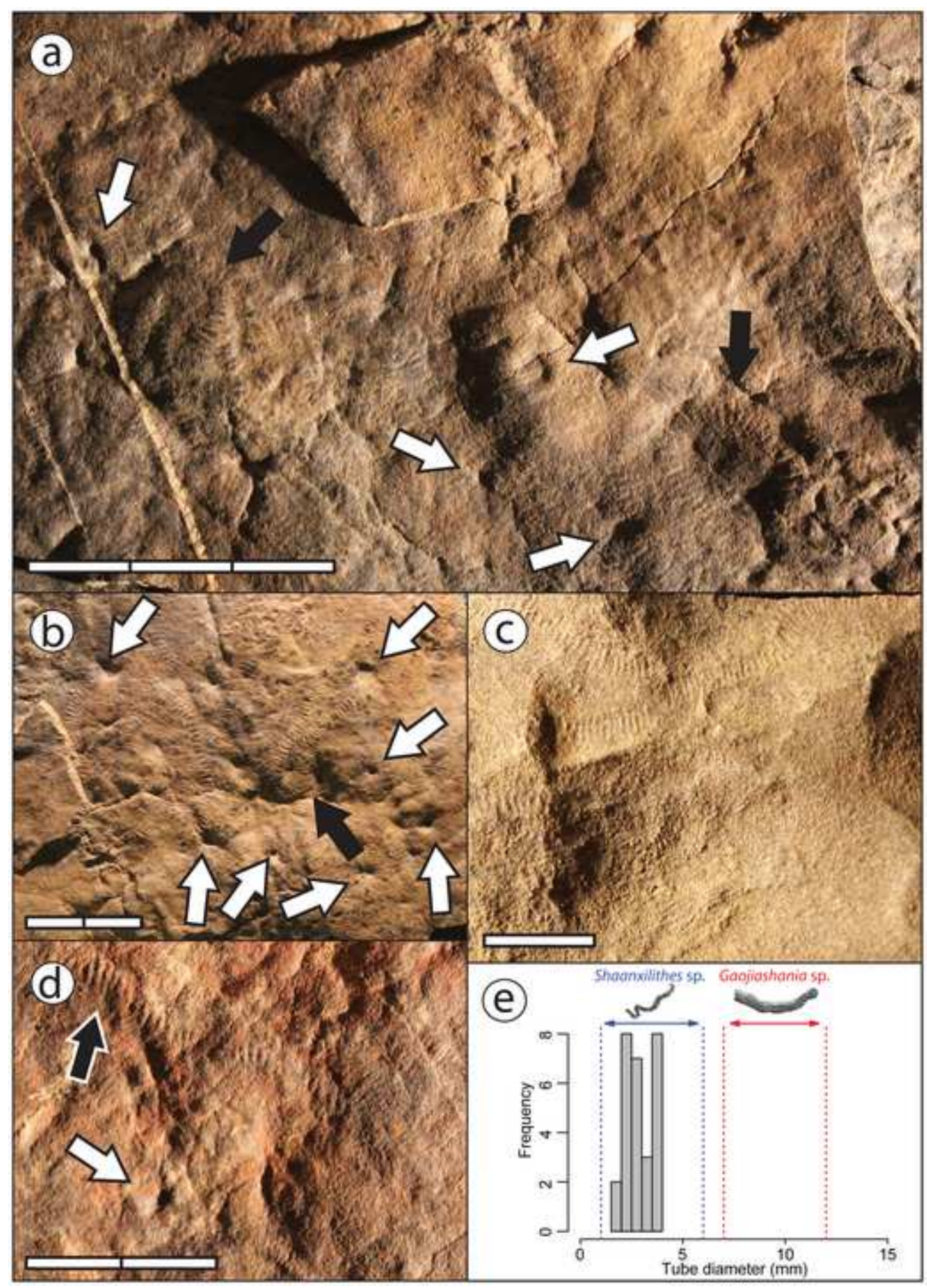
. .

\section{.}

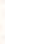

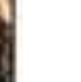

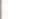

